\title{
LEARNING BY DOING: IMPLEMENTING IN MICROCONTROLLER COURSE
}

\author{
Nethravathi.S ${ }^{1}$, R.S.Geetha ${ }^{2}$ \\ ${ }^{1}$ Assistant Professor, ${ }^{2}$ Associate Professor \\ ${ }^{1,2}$ Electrical \& Electronics Engineering, \\ BMS College of Engineering, Bangalore, India \\ ${ }^{1}$ nethrapallavi@gmail.com \\ ${ }^{2}$ rsgeetha.eee@bmsce.ac.in
}

\begin{abstract}
Many Engineering applications use microcontrollers as one of the important component. Hence, in our curriculum, Microcontrollers course is one of the core subjects for the undergraduate students of Electrical and Electronics stream. Traditionally, the course was taught as a theory subject in classrooms, accompanied by practical sessions. However, it was observed from the course end survey that, the students were not able to appreciate the subject, as they were not involved in applying the concepts in developing a project. In this paper, an alternative approach of teaching Microcontroller course with emphasis on projects or open ended experiments along with traditional method of teaching is presented. The learning level of the students is found to be increased with this approach. The method is also found to improve students' logical ability and spirit of team work.
\end{abstract}

Keywords-Microcontrollers; Project based learning; Open Ended Experiments;

\author{
Nethravathi.S $\mathbf{S}^{1}$ \\ ${ }^{1}$ Assistant Professor, \\ ${ }^{1}$ Electrical \& Electronics Engineering, \\ BMS College of Engineering, Bangalore, India \\ ${ }^{1}$ nethrapallavi@gmail.com
}

\section{INTRODUCTION}

Introduction of technology has changed the way in which we analyze and control the world around us. Computer on chip or microprocessor was first introduced in 1971 by Intel Corporation. A by-product of microprocessor development was the microcontroller. The same fabrication techniques and programming concepts that make possible the general-purpose microprocessor yielded the microcontroller which is specific purpose[1]. In our curriculum, Microcontrollers course is a mandatory course in Undergraduate level. It is a one semester course which is studied by the students belonging to Electrical Science cluster. The course is basically designed for 8051 Microcontroller and is taught for second year students.

Earlier, the course was taught in a classical way, wherein, much emphasis was given on teaching the architecture, instruction set with examples, and the concept of interfacing some hardware circuits such as Digital to analog converters, Analog to digital converters, Keyboard display, Stepper motor, etc.In the associated practical sessions, the students would execute a set of pre-defined programs using IDE, PICsim, KEIL Software, etc., and therefore, the learning process was limited to a boundary.

In order to enhance the learning level of the students and to apply the Microcontrollers to solve Engineering problems, another component has been added into the teaching method, that is, projects and open ended experiments. In this paper, the results of implementing Open ended experiments and Project based learning and comparison of same with respect to traditional way of teaching are presented.

\section{MICROCONTROLLER COURSE}

Microcontroller is a microprocessor with added features, which makes it a complete computer. The added features are ROM, RAM, parallel I/O, serial I/O, counters and a clock circuit. The prime use of a microcontroller is to control the operation of a machine using a fixed program that is stored in ROM and that does not change over the lifetime of the system[1],[2]. 
Teaching the course earlier comprised of classroom teaching and practical sessions only. In classroom teaching theory was taught, emphasizing on the architecture in the beginning, followed by the instructions set descriptions and writing small programs. The program writing was done both in Assembly language and C Programming. The last part of the course was to expose the students to some limited applications such as interfacing keyboard, Stepper motor, DC motor, LCD display and temperature controller. In laboratory, initially students executed a set of simple programs using KEIL Software.In the later part of the lab course students executed the interfacing programs using the Microcontroller Development board using Integrated Development Environment (IDE). The development board is as shown in Fig. 1.

Though this method of teaching the course is a wellestablished one, it gives very little exposure to the practical engineering applications. In order to bring in enthusiasm in learning 8051 Microcontrollers, we introduced project based learning and open ended experiments to the lab component in the course. Through these alternate methods, the students get experienced about writing the programs for a particular application and learn to develop the hardware too.

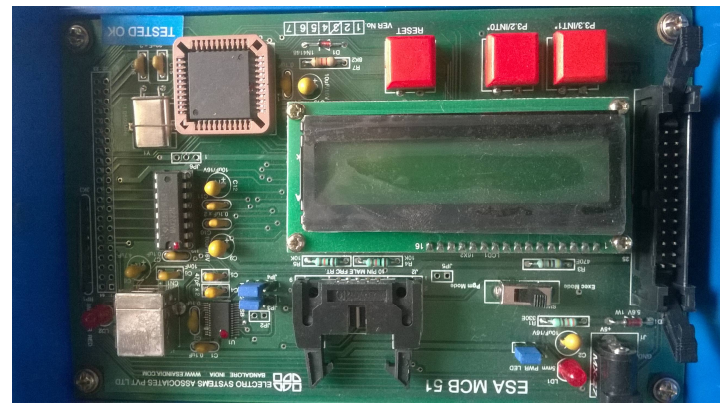

Fig.1: 8051 Microcontroller development board

\section{ALTERNATE METHODS OF LEARNING}

The Accreditation council insists that an engineering graduate must beable to designand conduct experiments, analyze and interpret the data, and should also be able to work in a group[3]. This will enable students to utilize the knowledge gained from the laboratory work to become young engineers, whoare not only well-versed in theory, but are also efficiently able to handle real time situations.

Here, two alternate methods are presented that were implemented for two successive batch students in the Department of Electrical and Electronics Engineering during 2013 and 2014. In both these methods, the classical method of teaching was still retained, and an additional component of project / open ended experiment was introduced as a part of the lab course. The results are compared with the method, where the course was taught traditionally.

\section{A. PROJECT BASED LEARNING(PBL):}

In this method of learning, the students were trained initially for executing small programs using both Assembly and Embedded $\mathrm{C}$ language. They had to implement a small project towards the end of the semester. A list of projects was given by the course coordinators and the students in a group of two or three were to select one of the projects.
The list included projects such as designing a security system, fault indication system, clock, visitor counter, color sensor, electronic dice, over-speed detector, IC tester, voting machine etc.

Once the project was decided, they had to decide upon the components required, cost and the coding for the project. In this process, they had to interact with each other, build the spirit of team work in realizing a working project. After completing the project, they had to give a presentation and submit a brief report on the project for which they were evaluated.

Some of the pictures of the projects implemented are shown in Fig. 2 and Fig. 3.

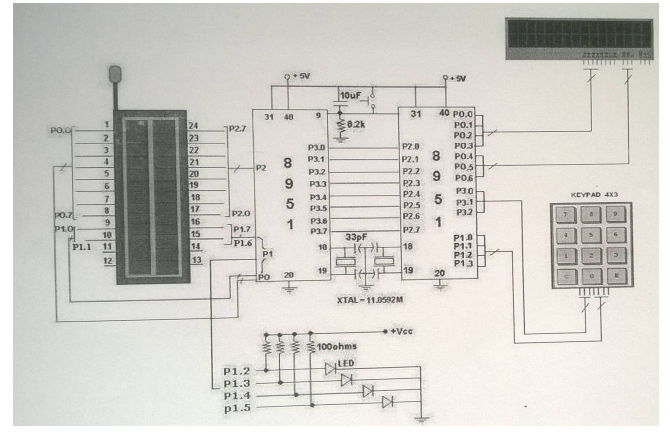

Fig. 2: 89c51 based IC Tester

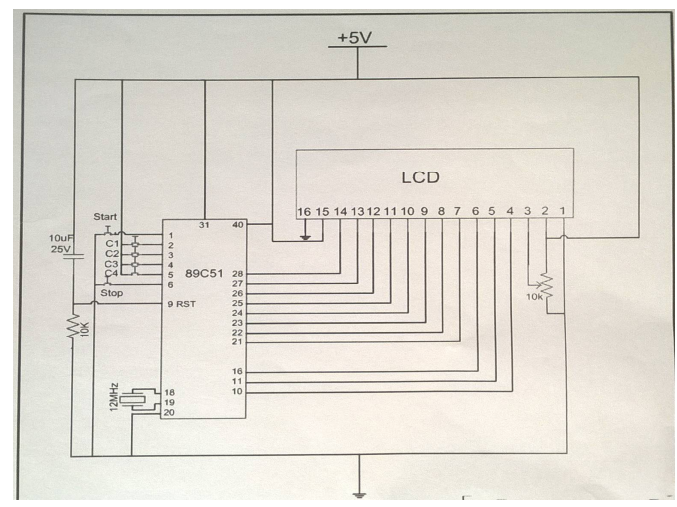

Fig. 3: LCD Based Voting Machine using 8051

\section{B. OPEN ENDED EXPERIMENTS (OEE):}

In the open-ended style, the problem may have multiple solutions and there is no best way of solving theproblem, and hence, the students have to work theoretically and practically. Hence, this makes the laboratory class moreexplorative in the sense that students use their own initiative and creativity to design their own experiments.Due to the nature of OEE, students can improve their learning ability, encourage their individual creativity, gain self-confidence and feel the design environment for real industry outside the academic world [3].

For this reason, most of the laboratory work done in many scientific areas currently embraces open-ended working. OEEs are also linked to authentic student achievement, so students can actively experience thefeelings of practicing professionals. One important aspect of OEE is that students need high self-motivationand, students with 
weaker attitudes need more support to meet the challenge of OEE[3].

In this alternative method, the students were free to select the method of approach and execution of a given OEE. Some of the OEE executed by the students include displaying animations on 7 segment display, Quiz buzzer, Water level indicator, etc. The students were asked to make groups consisting of 3-4 members in each group. They carried out the experiment using the Microcontroller development board available in the lab. The positive side of this approach of learning is that, they need not worry about the cost and components required for implementation. More emphasis here was for writing an optimum code using the available resources. They executed the experiment during their free time and discussed with the course instructor whenever they had some clarifications. Hence the role of instructorwas changed to facilitator rather than a teacher. Some of the pictures of OEE implemented are shown in Fig. 4 and Fig.5.

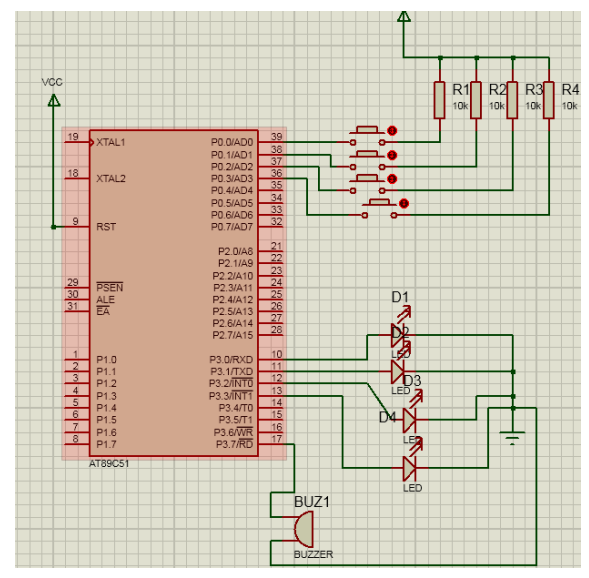

Fig. 4: Circuit for Quiz buzzer

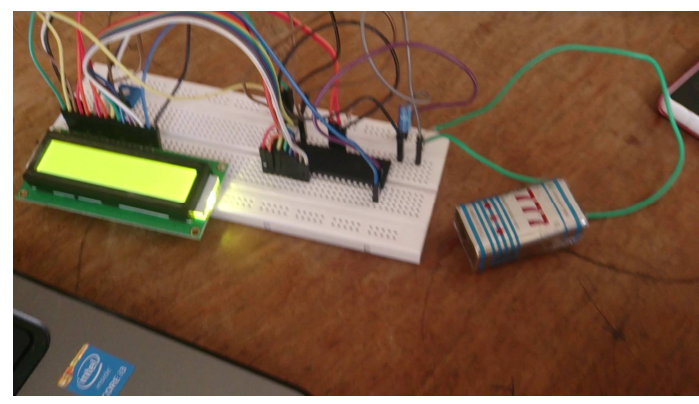

Fig. 5: Water Level Indicator

\section{ASSESSMENT METHODOLOGY}

While assessing the students, in traditional method, students would be given an experiment which has to be executed and the result would be shown to the instructor. On successfully executing the program, student would be given marks based on his/her ability to debug the program, execution and writing the record, which student would have maintained for the whole semester. In this method of assessment, student is just tested for his memorizing ability and writing records, which does not serve the purpose for a $21^{\text {st }}$ century engineer.

With the implementation of PBL and OEE, the teaching methodology takes a shift from traditional method to a new paradigm. With this new approach, student gets hands on experience of building a project. The following table summarizes the comparison of teaching methodology after implementing project based learning and open ended experiments with the traditional laboratory experiment evaluation.

TABLE 1: SUMMARY OF TEACHING METHODOLOGY

\begin{tabular}{|l|l|l|}
\hline Method & PBL/OEE & $\begin{array}{l}\text { Laboratory } \\
\text { Experiment }\end{array}$ \\
\hline Teaching Theory & & $\sqrt{ }$ \\
\hline Manual & & $\sqrt{ }$ \\
\hline Report & $\sqrt{ }$ & \\
\hline Experiment & $\sqrt{ }$ \\
\hline Team Work skill & $\sqrt{ }$ & \\
\hline $\begin{array}{l}\text { Practical } \\
\text { Evaluation }\end{array}$ & & \\
\hline
\end{tabular}

Table 2 shows the rubrics adopted for assessment of projects and open ended experiments. Students are evaluated according to the ratings given in the rubrics. This helps in uniform distribution of the marks for the students according to his/her contribution towards the completion of project.

In the rubrics, the first attribute considered for evaluation is the selection of the project within the scope of the subject. Second attribute is the method selected for the execution of the project. This deals with the software selected and the type of hardware chosen. Next attribute is the component selection, i.e., the selection of components based on cost, reliability and efficiency. The attribute contributing for the practical skill evaluation tells about the ability of a student to identify and solve complex problems.

After executing the project, student must be able to convey the process through proper discussion with the faculties. This is judged by the attribute, analysis and discussion. Also the same should be reflected in the form of report submitted. This attribute judges the writing skills of a student.

The project selected, must be applicable in the real world and should not be outdated. Otherwise the project becomes a dummy one. One attribute evaluates the application of the project in the present world.

At the time of executing a project, cost plays an important role. Any model developed by an engineer must be sellable. For this to happen, the product must be cost effective. Hence cost effectiveness is one criterion for the evaluation.

Lastly, the team work plays a very important role for successful completion of any project. Once a student 
graduates and takes up job, he/she should be able to work in teams and contribute maximum for the team work. So one of the attribute for evaluation is team work.
In the rubric adopted for evaluation, most of the attributes are for group evaluation and few attributes are for individual student performance evaluation

TABLE 2: RUBRICS ADOPTED FOR STUDENT EVALUATION

\begin{tabular}{|c|c|c|c|c|}
\hline $\begin{array}{c}\text { RATING } \rightarrow \\
\text { ATTRIBUTE } \downarrow\end{array}$ & Poor ( rating 1) & Fair (rating 2) & Good (rating 3) & Excellent (rating 4) \\
\hline $\begin{array}{l}\text { Relevance to the } \\
\text { subject }\end{array}$ & Not at all relevant. & $\begin{array}{l}\text { Fairly Relevant, but not } \\
\text { completely related to the } \\
\text { subject. }\end{array}$ & $\begin{array}{l}\text { Relevant but not able to } \\
\text { justify. }\end{array}$ & $\begin{array}{l}\text { Relevant and able to justify } \\
\text { and use of the concepts of } \\
\text { theory is well defined. }\end{array}$ \\
\hline Method of execution & $\begin{array}{l}\text { Method selected is outdated/ } \\
\text { not in use. }\end{array}$ & $\begin{array}{l}\text { Method selected has some } \\
\text { limitations. }\end{array}$ & $\begin{array}{l}\text { Method selected is good } \\
\text { but not convincing. }\end{array}$ & $\begin{array}{l}\text { Best method of execution } \\
\text { selected and comparison } \\
\text { done with other methods } \\
\text { available. }\end{array}$ \\
\hline $\begin{array}{l}\text { Selection } \\
\text { components }\end{array}$ & $\begin{array}{l}\text { Unable to describe } \\
\text { and classify components } \\
\text { available } \\
\text { to be used for specific } \\
\text { purpose. }\end{array}$ & $\begin{array}{l}\text { Able to describe and } \\
\text { classify components } \\
\text { available but unable to use } \\
\text { and apply them. }\end{array}$ & $\begin{array}{l}\text { Able to compare or } \\
\text { evaluate results obtained } \\
\text { using more than one } \\
\text { component. }\end{array}$ & $\begin{array}{l}\text { Able to combine, } \\
\text { compare or evaluate } \\
\text { results obtained } \\
\text { using more than one } \\
\text { component. }\end{array}$ \\
\hline Practical skill & $\begin{array}{l}\text { Unable to identify and solve } \\
\text { problems in complex } \\
\text { situations found. }\end{array}$ & \begin{tabular}{l}
\multicolumn{2}{l}{ Unable to identify and solve } \\
problems in complex \\
situations found with \\
marginal \\
judgment
\end{tabular} & $\begin{array}{l}\text { Able to identify and } \\
\text { solve problems in complex } \\
\text { situations and make good } \\
\text { justifying judgment. }\end{array}$ & $\begin{array}{l}\text { Able to clearly identify and } \\
\text { aptly solve problems in } \\
\text { complex } \\
\text { situations and } \\
\text { develops complete and } \\
\text { innovative solution to meet } \\
\text { varying requirements while } \\
\text { making excellent } \\
\text { justifying judgment. }\end{array}$ \\
\hline $\begin{array}{l}\text { Analysis } \\
\text { Discussion }\end{array}$ & $\begin{array}{l}\text { Discussion of } \\
\text { results is inappropriate and } \\
\text { shows lack of } \\
\text { comprehension of } \\
\text { scientific concepts. }\end{array}$ & $\begin{array}{l}\text { Discussion of results } \\
\text { does not identify } \\
\text { appropriate concepts, } \\
\text { needs significant } \\
\text { work and / or shows } \\
\text { a weak grasp of } \\
\text { concepts. }\end{array}$ & $\begin{array}{l}\text { Discussion of results } \\
\text { needs some refinement but } \\
\text { shows a reasonably } \\
\text { strong grasp of the } \\
\text { scientific concepts. }\end{array}$ & $\begin{array}{l}\text { Discussion of results } \\
\text { shows a strong grasp of the } \\
\text { scientific concepts. }\end{array}$ \\
\hline $\begin{array}{l}\text { Application in the } \\
\text { real world }\end{array}$ & Does not find any application. & $\begin{array}{l}\text { Idea finds application but } \\
\text { with modifications. }\end{array}$ & $\begin{array}{l}\text { Finds application with } \\
\text { little modification. }\end{array}$ & $\begin{array}{l}\text { Totally applicable to the } \\
\text { present world. }\end{array}$ \\
\hline Report writing & $\begin{array}{l}\text { Purpose of work } \\
\text { with relevant } \\
\text { background } \\
\text { information } \\
\text { missing. Report } \\
\text { is poorly organized. }\end{array}$ & $\begin{array}{l}\text { Purpose of work } \\
\text { with relevant } \\
\text { background } \\
\text { information missing. } \\
\text { Report is still } \\
\text { reasonably well } \\
\text { organized. }\end{array}$ & $\begin{array}{l}\text { Purpose of work } \\
\text { with relevant } \\
\text { background } \\
\text { information available } \\
\text { but not completely } \\
\text { provided. The report is still } \\
\text { well organized. }\end{array}$ & $\begin{array}{l}\text { Purpose of work with } \\
\text { relevant background } \\
\text { information sufficiently } \\
\text { provided and the report is } \\
\text { very well organized. }\end{array}$ \\
\hline Cost Effectiveness & Cost is too high. & $\begin{array}{l}\text { Cost is high but still could } \\
\text { be reduced. }\end{array}$ & $\begin{array}{l}\text { Cost is reasonable and } \\
\text { selection of components / } \\
\text { hardware is good. }\end{array}$ & $\begin{array}{l}\text { Cost is cheap with best } \\
\text { selection of components / } \\
\text { hardware available. }\end{array}$ \\
\hline Team work & $\begin{array}{l}\text { Unable to work and } \\
\text { refuses to interact } \\
\text { with others }\end{array}$ & $\begin{array}{l}\text { Able to work but } \\
\text { with less interaction with } \\
\text { others. }\end{array}$ & $\begin{array}{l}\text { Able to work and } \\
\text { interacts with others. }\end{array}$ & $\begin{array}{l}\text { Enjoys work and } \\
\text { always motivates } \\
\text { other group members. }\end{array}$ \\
\hline
\end{tabular}

\section{COMPARISON OF THE SAID METHODS}

The comparison of the three methods adopted for course delivery yields that the project based learning and implementing open ended experiments provide better platform for independent learning, practical exposure, innovation and team work capabilities of a student.

Course outcomes (CO)and program outcomes (PO) defined are better met with PBL and OEE methods. Table 3 gives the attainment of course outcomes and program outcomes for 2011,2012 and 2013 batch students where traditional method of teaching, PBL and OEE were implemented respectively.

The COs defined for the subject are:
CO1: Ability to apply the engineering fundamentals to identify and differentiatebetween controller and processor architectures.

CO2: Ability to analyze and develop programs using assembly code and embedded'c' code to solve different engineering problems.

CO3:Ability to design and test solutions for engineering problems using systemcomponents of a Microcontroller.

The POs attained are defined as:

PO1: Apply the knowledge of mathematics, science and engineering principles

PO2: Formulate and analyze complex engineering problems.

PO3: Design solutions that meet specific societal needs. 
PO4: Design and conduct experiments TABLE 3: ATTAINMENT OF COs AND POs

\begin{tabular}{|l|l|l|l|}
\hline \multirow{2}{*}{ COs } & \multicolumn{3}{|l|}{ CO Attainment on a scale of 1 } \\
\cline { 2 - 4 } & $\mathbf{2 0 1 1}$ & $\mathbf{2 0 1 2}$ & $\mathbf{2 0 1 3}$ \\
\hline CO1 & 0.875599 & 0.833407 & 0.904319 \\
\hline CO2 & 0.948681 & 0.677537 & 0.868182 \\
\hline CO3 & 0.9684 & 0.8754 & 0.9186 \\
\hline
\end{tabular}

\begin{tabular}{|l|l|l|l|}
\hline \multirow{2}{*}{ POs } & \multicolumn{3}{|l|}{ PO Attainment on a scale of 1 } \\
\cline { 2 - 4 } & $\mathbf{2 0 1 1}$ & $\mathbf{2 0 1 2}$ & $\mathbf{2 0 1 3}$ \\
\hline PO1 & 0.93 & 0.8 & 0.897 \\
\hline PO2 & 0.93 & 0.8 & 0.897 \\
\hline PO3 & 1 & 0.7555 & 1 \\
\hline PO4 & 1 & 0.7765 & 0.9485 \\
\hline
\end{tabular}

For 2011 batch, the students had to conduct a set of predefined experiments as instructed by the course coordinators. Hence as observed from the Table 3, the CO and PO attainment factors are quite high $(>0.87)$. But there was no scope for any innovation or implementing their own ideas during the practical sessions.

For 2012 batch, PBL was introduced as a part of the lab component. As seen from the table, the PO attainments are lesser when compared to those of 2011 batch. This is because the students were evaluated for different parameters as listed in Table 2.

For 2013 batch, OEE method of teaching was implemented. A lot of interactions happened between the students and the course instructors during the implementation of OEE method. This has reflected in an improvement in the $\mathrm{CO}$ as well as $\mathrm{PO}$ attainment as seen from Table 3. The parameters considered for evaluation are same as that of listed in Table 2.

The attainment factor of COs and POs helps the course instructor for adopting quality improvement measures for the next batch of students in the next academic year.

The following table gives the additional POs met along with the POs listed in Table 3 when PBL/OEE methods of learning are implemented.

\section{TABLE 4: ADDITIONAL POs}

\begin{tabular}{|l|l|l|}
\hline Additional POs & $\begin{array}{l}\text { Traditional } \\
\text { Learning }\end{array}$ & PBL/OEE \\
\hline $\begin{array}{l}\text { Select and apply appropriate modern } \\
\text { engineering tools }\end{array}$ & $\sqrt{ }$ & $\sqrt{ }$ \\
\hline $\begin{array}{l}\text { Understand the impact on societal } \\
\text { and environmental contexts. }\end{array}$ & $\sqrt{ }$ \\
\hline $\begin{array}{l}\text { Understand ethical principles and } \\
\text { social issues }\end{array}$ & & $\sqrt{ }$ \\
\hline $\begin{array}{l}\text { Function effectively as an individual } \\
\text { and also as team member or leader. }\end{array}$ & & $\sqrt{ }$ \\
\hline Communicate effectively & & $\sqrt{ }$ \\
\hline Independent and Lifelong Learning & & \\
\hline
\end{tabular}

\section{CONCLUSION}

From the experience, it is observed that the implementation of PBL and OEE nurtures the capability of a student in inculcating best practices for solving engineering problems. It is observed that a student applies his/her creativity and innovation to come out with the best possible solution.

\section{References}

[1] "The 8051 Microcontroller" by Kenneth Ayala.

[2] "The 8051 Microcontroler and Embedded Systems" by Muhammad Ali Mazidi, Janice Gillispie Mazidi and Rolin D McKinlay.

[3] Zaiton Haron, Shahrin Mohammad, Abdul RahmanMohd Sam, MushairryMustaffar, JamaludinMohdYatim, "The Implementation of an Open-Ended Experiment in the Civil Engineering Laboratory, 6th International Forum on Engineering Education (IFEE 2012) 